\title{
EVALUATION OF MEASURES TO REDUCE EMPLOYEE TURNOVER IN SLOVENIAN ORGANISATIONS
}

\author{
Jernej Buzeti, Maja Klun, Janez Stare
}

\section{Introduction}

Employee turnover is studied by various scientific disciplines (psychology, sociology, organisational science and economics). The economic aspect of employee turnover primarily has to do with examining factors that affect employee absence and change of employment. According to its economic definition, employee turnover is an adjustment in the supply of an individual's labour capacity with regard to satisfaction with working conditions in the broadest sense of the term (Yaniv, 1995). The reasons for a job change by an individual are studied as part of the economic approach. From the perspective of the employer, the central issue is that of costs incurred by employees leaving their jobs and the 'price' the employer is willing to pay for certain motivational elements that would reduce job changing (Karan, 2011). Determining the reasons why employees leave their jobs is a major challenge, since what for one employee may be the reason to leave a job may be another's reason to keep it. Most employees are dissatisfied with communication from the top down, poor interaction among coworkers, the lack of trust and etc. Most often, the true reasons for leaving one's job remain obscure or are interconnected and complex.

Studies of employee turnover mainly focus on the aspect of the employee. They focus primarily on the relationship between the rate of employee turnover and the efficacy and efficiency of an organisation (e.g. Shaw, Gupta, \& Delery, 2005; Kacmar et al., 2006; Yanadori \& Kato, 2007; Aa, Bloemer, \& Henseler, 2012). Earlier studies have found that a lower turnover rate improves the efficiency of an organisation, while the studies mentioned above find also a negative correlation. Employee turnover is a topic that is increasingly being discussed in conjunction with human resources management in large organisations as well as in terms of setting the strategic goals of an organisation. In the planning of human resources the issues of employee turnover and of a strategy to address it come up sooner or later. In addition to the parameters that only impact absence from work such as affiliation with an organisation, motivation and pay, employee turnover is also significantly affected by various fringe benefits (flexible working hours, insurance, pension schemes, etc.) (Mitchell, 1983; Lee, $\mathrm{Hsu}$, \& Lien, 2006). The allocation of fringe benefits is associated with the expenses of the organisation, which is why it is important to determine what portion of these costs the organisation is prepared to cover. Therefore the issue of employee turnover in most studies mainly concerns the level of the organisation as a whole, individuals or branch (Bennett, 1993; Lee, Hsu \& Lien, 2006; Cohen, 1999). According to Chang, Wang \& Huang (2013) most management research and turnoverintention studies also involved single level studies.

The key problems of employee turnover for the company are the loss of skills possessed by the employee and the associated costs. For the purpose of their study, Parise et al. employed an approach called "organisational network analysis" (ONA), which helped them identify the weak points of corporate knowledge on the basis of employee knowledge and how their departure would affect the network (Parise, Cross, \& Davenport, 2006). At the same time they define specific problems arising from the loss of knowledge in relation to the role that employees play in the company.

In our paper we endeavour to contribute to this research especially in terms of estimating the cost of reducing employee turnover. The value the paper adds to previous research is multidimensional. This is a study that covers all industrial sectors in a single EU country 
(Slovenia) and does not focus on one sector only. Some studies that include several industries (Nobscot Corporation, 2006) indicate that employee turnover rates vary depending on the industry, which has not been confirmed by our study. The estimated costs are also the result of comparing the preferences of employees and employers in relation to measures to prevent employee turnover. As has already been mentioned, studies have sought causes mainly from the aspect of employees, while the costs of employee turnover are estimated for employers and include only the estimated costs of the departure of an employee and the recruitment of a new one. As this is the first such study in Slovenia, it contributes to other studies that focus on particular countries or activities.

\section{Costs of Employee Turnover}

Employee turnover may be voluntary or involuntary. The former should not cause any particular problems as it is assumed that the company will make arrangements for replacing an employee if it dismisses him/her. Major problems may result from involuntary employee turnover, especially when a company is not prepared for it (Karsan, 2007; Rosch, 2001). When managing employee turnover costs, it is useful to know the critical cost categories associated with turnover. Employee turnover involves the following costs:

- the cost of dismissal or departure of an employee,

- the cost of hiring a new employee,

- the cost of training a new employee,

- the cost of lost time until the new employee achieves full productivity,

- the cost of unused production capacity during the period of adjustment of the new employee.

The indirect costs of employee turnover may also include: the costs of loss of business and/ or clients, building new relationships between employees (the new employee may also impact the reduced productivity of other employees), the loss of training an employee who is leaving his/her job.

Studies relating to the costs of employee turnover mainly focus on particular industries (restaurants, hotels, security, etc.), but there are no comprehensive studies. Empirical studies have shown that high employee turnover significantly increases costs for organisations (e.g. Tracey, 2008; Dalton et al., 1995; Waters, 2003). Studies show that employee turnover costs are higher in more complex, more independent and better-paid jobs and those that require greater efforts. According to some data, the costs of replacing a worker reach an average of one third of the annual earnings of a new employee (Michaud, 2000), while others estimate these costs at $25 \%$ (Ettorre, 1997). For the most part, these are rough estimates based on partial studies in different industries. One of the commonly used models was developed by Cascio (2000). It is a mathematical approach linking the costs of an outgoing and an incoming employee. McKinney et al. (2007) further developed this model.

There are fewer studies that focus on estimating the costs of measures for reducing unwanted employee turnover (Milkovich, Newman \& Milkovich, 2005; Bohlander, Snell \& Sherman, 2001; Lee, Hsu, \& Lien, 2006). In a study conducted in 2010 the author asks whether the rate of employee turnover in Europe will rise to the level in the U.S. because of changes in the labour market (Rhein, 2010). The study included six EU-15 countries that account for $80 \%$ of all EU citizens. The selected countries (Germany, France, Italy, Great Britain, Spain and Denmark) also have a very different organisation of the labour and employment market, the level of social security and the level of regulation in the area of employment, and differences also exist in the introduction of reforms in the labour market. Until 2008, Germany, France and Italy had a relatively low rate of employee turnover, which may be due to a better regulated labour market and lower employee mobility. It was also found that in these countries employees remained with the same employer for 10 or more years. Quite the opposite is true of Great Britain, Spain and Denmark, where employee turnover rates increased significantly in the early 1990s (Rhein, 2010). The differences in employee turnover rates between the countries of the European Union in 2008 were studied by the Federation of European Employers (2011). The annual employee turnover rate represents the percentage of employees who changed jobs in the last three months. The rate varies considerably depending on the proportion of employees who are employed for a fixed or indefinite period. In 2008, Slovenia was just below the EU average of $4.8 \%$ with a $4.4 \%$ employee turnover rate. 
Our study aimed to estimate both groups of costs. From an economic point of view, the elements most important for reducing employee turnover are direct financial expenses (wages and bonuses, training, the cost of regulating working conditions) and indirect expenses (the opportunity costs of the time required for regular internal communication, career development, trust building). The importance of individual measures was tested in the study we conducted in 2011. The hypothesis tested was as follows:

$\mathrm{H}$ : Employees and employers similarly value measures to reduce unwanted employee turnover.

Another purpose of the study was to estimate the average costs of replacing an employee in Slovenia in an organisation.

\section{Methodology}

In this study we used two samples: employers from all economic sectors in Slovenia and employees, also from all sectors in Slovenia. The survey was conducted at the beginning of 2011. Data was collected using the CAWI (Computer Assisted Web Interview) method and a questionnaire that could be completed by all study subjects invited on the basis of a received electronic invitation. A total of 18,175 companies from all sectors and from all parts of Slovenia were invited to participate. The companies were randomly selected for the sample on the basis of the criterion of a publicly available website with a publicly available email address or an electronic address published in different business directories (PIRS, TIS, etc.). The questions were answered by 917 representatives of companies, or $5 \%$ of all those invited to participate in the study. The second sample was larger as more than 20,000 employees were invited through various employee associations (trade unions, workers' associations, employee stakeholder groups) that have publicly available websites. The exact number is difficult to determine because not all information about the members of various associations is known. We received 942 completed questionnaires.

For the purposes of our study, both groups evaluated measures to reduce employee turnover with ratings ranging from 1 (don't agree at all) to 5 (agree completely). Both questionnaires also included questions related to the demographic characteristics of the respondents (gender, age, industry, seniority, etc.). In an additional questionnaire, along with the evaluation of measures, employers also evaluated the costs of each measure and the time used for hiring new employees.

\section{Results}

We first wanted to verify whether the set of measures that were evaluated by both groups and which had been determined on the basis of various empirical studies were assessed as important for reducing employee turnover.

\section{Tab. 1: Nonparametric $\chi^{2}$ test for given measures}

\begin{tabular}{l|r|r|r} 
& Chi-Square & \multicolumn{1}{|c|}{ df } & \multicolumn{1}{c}{$\begin{array}{c}\text { Asymp. } \\
\text { Sig. }\end{array}$} \\
\hline Possibility of additional training & $1,050.813$ & 4 & .000 \\
\hline Trust in management & $1,045.889$ & 4 & .000 \\
\hline Career opportunities & $1,347.563$ & 4 & .000 \\
\hline Subsidising informal meetings & 442.626 & 4 & .000 \\
\hline Good working conditions & $2,427.418$ & 7 & .000 \\
\hline Praise (public and direct) & $2,497.971$ & 8 & .000 \\
\hline Subsidizing various benefits (medical examinations, pension & $2,211.483$ & 15 & .000 \\
\hline savings, day care for employees' children...) & $1,875.571$ & 9 & .000 \\
\hline Flexible working conditions (flexible working hours, work from home) & 695.458 & 4 & .000 \\
\hline Higher pay & $1,192.050$ & 8 & .000 \\
\hline Job stability (continuity of employment) & & & \multicolumn{2}{|c}{ Source: own }
\end{tabular}


Nonparametric $\chi^{2}$ tests confirmed statistically significant differences for all statements between the observed and expected frequencies $(p<0.000)$, which means that all the measures were assessed as important for reducing employee turnover.

It is evident from the frequency distribution of ratings by both groups of respondents across the measures that employers consider good working conditions and higher pay as the most common measures. These are followed by praise, career opportunities and training. Interestingly, employers' highest disagreement concerns the measure of rewarding employees for workplace attendance and the continuity of employment. The evaluations of other parameters indicate that employers recognise the financial measure as the most effective one for preventing employee turnover.

Although the order of measures differs between the two groups, it is evident that the measures that received the highest ratings from employees received, on average, lower ratings than those given by employers, i.e. they considered them less important. Practically, all potential measures for reducing employee turnover were rated lower by employees than by employers. Interestingly, employees on average gave higher ratings to measures that require less financial investment by employers since measures associated with direct expenditure by employers were given a lower average rating. It is evident that the ratings of measures differ between the two groups, particularly in terms of their order. This result is important for human resources management in an organisation as it indicates essential differences between the two groups and thus the possibility of proposing various measures and their assessments. The measure that is closest to the top in both groups is "career opportunities".

We found out that there were no significant statistical differences in the estimates of measures between sectors or in relation to other characteristics of employees and employers. There were some differences among employees regarding some measures according to their education (those with higher education prefer praise more than others) and according to their age (older employees prefer job stability more), but even there were no difference between sectors or position at work.

For claims that were identical in both groups of respondents we also conducted the Mann-Whitney test whereby we intended to either confirm or reject the hypothesis that the

\begin{tabular}{|c|c|c|}
\hline $\begin{array}{l}\text { Tab. 2: Comparison of responses about measure } \\
\text { between employers and employees }\end{array}$ & prevent employ & turnover \\
\hline & $\begin{array}{c}\text { Average rating - } \\
\text { employees }\end{array}$ & $\begin{array}{l}\text { Average rating - } \\
\text { employers }\end{array}$ \\
\hline Higher pay & 2.31 & 4.47 \\
\hline Trust in management & 3.91 & 4.09 \\
\hline Good working conditions & 4.24 & 4.46 \\
\hline Praise (public and direct) & 4.02 & 4.34 \\
\hline Possibility of additional training & 3.99 & 4.17 \\
\hline Career opportunities & 4.10 & 4.22 \\
\hline $\begin{array}{l}\text { Flexible working conditions (flexible working hours, } \\
\text { work from home) }\end{array}$ & 3.73 & 4.10 \\
\hline Subsidising informal meetings & 3.15 & 3.93 \\
\hline $\begin{array}{l}\text { Subsidising medical examinations, pension savings, day } \\
\text { care for employees' children, snacks and beverages in the } \\
\text { workplace, work-related costs... }\end{array}$ & 3.74 & 3.62 \\
\hline Job stability (continuity of employment) & 4.28 & 3.07 \\
\hline
\end{tabular}




\begin{tabular}{|c|c|c|c|c|}
\hline \multirow[t]{2}{*}{ Tab. 3: } & \multirow[b]{2}{*}{$\begin{array}{c}\text { Mann-Whitney } \\
\text { U }\end{array}$} & \multirow[b]{2}{*}{ Wilcoxon W } & \multirow[b]{2}{*}{$\mathbf{z}$} & \multirow[b]{2}{*}{$\begin{array}{c}\text { Asymp. } \\
\text { Sig. } \\
\text { (2-tailed) }\end{array}$} \\
\hline & & & & \\
\hline Higher pay & $95,765.500$ & $334,851.500$ & -25.352 & .000 \\
\hline Possibility of additional training & $343,725.500$ & $671,370.500$ & -2.801 & .005 \\
\hline Trust in management & $353,015.500$ & $682,281.500$ & -1.934 & .053 \\
\hline Career opportunities & $359,668.000$ & $780,571.000$ & -1.176 & .240 \\
\hline Subsidising informal meetings & $236,277.500$ & $558,280.500$ & -13.270 & .000 \\
\hline Job stability (continuity of employment) & $162,777.500$ & $583,680.500$ & -20.666 & .000 \\
\hline $\begin{array}{l}\text { Flexible working conditions (flexible } \\
\text { working hours, work from home) }\end{array}$ & $369,406.000$ & $697,051.000$ & -.156 & .876 \\
\hline Praise (public and direct) & $343,987.500$ & $672,442.500$ & -2.777 & .005 \\
\hline $\begin{array}{l}\text { Subsidising medical examinations, } \\
\text { pension savings, day care for } \\
\text { employees' children, snacks and } \\
\text { beverages in the workplace, work- } \\
\text { associated costs... }\end{array}$ & $334,265.500$ & $755,168.500$ & -3.595 & .000 \\
\hline $\begin{array}{l}\text { Flexible working conditions (flexible } \\
\text { working hours, work from home) }\end{array}$ & $321,795.000$ & $647,823.000$ & -4.807 & .000 \\
\hline
\end{tabular}

Source: own

responses differed statistically between the two groups of respondents. It is evident from the table that the answers differ statistically between employers and employees in five of the measures (wages, subsidies for informal meetings, subsidies for various benefits, employment stability and flexible working conditions). Agreement with these claims is significantly lower among employees $(p<0.000)$.

\section{Evaluation of the Costs of Measures to Reduce Employee Turnover}

Since our intention was to evaluate the costs of measures, we wanted to obtain information in an additional questionnaire for employers about how much money on average they allocated for the selected measures. We mainly wanted to evaluate the costs of subsidising informal meetings, bonuses for the continuity of employment and bonuses for workplace attendance. Most other measures preferred by employees are of a non-financial nature, except for promotion, which we did not evaluate specifically as it is primarily part of the company's employment and job diversity policy. In order not to neglect this part, we still reviewed the methods of rewarding performance and the share of variable pay which differentiates individual performance. In order to present costs on a relative scale, we decided to evaluate them as a percentage of average gross wages in Slovenia for 2011. The average gross wage in 2011 was $€ 1,524.56$ (average of monthly gross wages).

Most $(78 \%)$ of the companies included in the study have different forms of performance rewarding. In most cases, it is the variable component of wages, with clear allocation rules. The scope of the variable component varies between companies, ranging from $20 \%$ to $100 \%$ of average gross wages. In companies where the share of the variable component is larger, payments are also more frequent, while in companies with a fixed bonus amount, the share of recipients is smaller. With regard to the number of employees, the share of recipients of performance bonuses and the bonus amounts, the annual average cost of rewarding performance is estimated to be 2.8 times the average annual wage in Slovenia. 
Bonuses for the continuity of employment or so-called loyalty bonuses are paid by all companies. They differ as to whether companies pay them according to overall seniority or seniority with the current employer. These bonuses are also paid in accordance with legal regulations, namely for the completion of $10,20,30$ and 40 years of service. Assuming that all companies pay loyalty bonuses in accordance with seniority and the age structure of employees, it can be estimated that companies' average annual cost of loyalty bonuses amount to 2.12 times the average monthly wage in Slovenia. If only seniority with the current employer is taken into account, this cost is lower.

Workplace attendance bonuses as a regular monthly payment were not paid by any of the companies surveyed. However, most companies correct their year-end bonuses (Christmas bonuses, profit sharing, etc.), which are fixed for the most part, in accordance with employees' workplace attendance. Most companies therefore take attendance into account when paying year-end bonuses. This can be deemed indirect workplace attendance rewarding. According to statistics, an average of about $€ 140$ in gross terms, or $7.6 \%$ of average wages, was paid per employee in Slovenia in 2011. This payment already includes the correction for workplace attendance, which is why we were unable to estimate the exact amount of the indirect attendance bonus.

The last measure of a financial nature that we estimated was the financing of informal meetings. All companies organise informal meetings at least once a year. Total annual funds for the organisation of these meetings vary between companies with regard to their size and the frequency of such meetings. On average, the companies surveyed used an average of $€ 2,500$, or 1.6 times the average monthly gross wages, for the organisation of such meetings.

It is evident that the highest cost is the variable component of wages, which we used to indirectly estimate the cost of promotion. If this cost is taken into account in full (it is essentially a wage-related cost) and if other costs are taken into account, it is evident that the average costs of the measures proposed by employees represent $€ 214,546.80$ per year or, on average, a little less than 141 gross average wages. The fixed components of wages and the indirect inclusion of workplace attendance in year-end payments were not taken into account. This is a relatively rough estimate of the costs as the amount is not weighted by company size, and the estimate is also based only on the population of the realised respondent sample. Bonuses and the variable components of wages are on average lower or absent in small companies. Slovenian companies are predominantly small businesses, which means that the weighting of the amounts by structure for the entire population would result in a lower value of the estimated costs.

\section{Estimate of the Costs of Employee Turnover}

In estimating the costs of employee turnover we focused only on the costs of hiring a new employee, which may be combined into two main groups:

- The cost of replacing an employee: vacancy announcement, candidate selection, interviews, reference checking, tests and requisite medical examinations and employment.

- The cost of introducing the new employee: the cost of training and opportunity costs of losses due to lower productivity.

- Indirect costs were not included in our estimate.

In our survey of Slovenian companies we examined where companies advertise vacancies and what are the costs of vacancy announcements, how much time they use for reviewing the applications received, whether they conduct interviews and tests, and who trains the new employee and how long it takes.

The results of the study showed that most companies advertise vacancies with the Employment Service of Slovenia and on their websites. Only $10 \%$ of the companies advertise vacancies in the printed media. The announcement of vacancies with the Employment Service of the Republic of Slovenia and on company websites is free of charge, while such announcements in various media outlets cost $€ 300$ on average. Most of the costs for the company are due to the time spent reviewing job applications. On average, the human resources department needs 5-10 minutes to review an application, depending on the certificates and annexes required by the call for applications. All companies conduct 
interviews, but only with selected candidates. No company invites all qualifying candidates to an interview, but make a short list first. On average, companies spend between 15 minutes and one hour on interviews per candidate. Companies spend on average between 5 hours (smaller companies) and 24 hours (larger companies) on calls for applications.

Companies have different approaches to introducing candidates to their new jobs. Some companies that have specific requirements for a certain job spend up to $€ 300$ in the first month of training. Other companies spend on average between 15 and 30 days on introducing new employees. Introduction also involves other employees. None of the companies provide new equipment for the workplace occupied by a new employee. According to some studies, the opportunity costs of productivity loss for a new candidate range from $67 \%$ (Tracey \& Hinkin, 2008) to $75 \%$ (Bliss, 2012) of the pay for the first month of employment. This means that a new employee performs only one quarter of the work of the previous employee in the first month. As this is the only assessment that was available, we estimated the cost of productivity loss as the average of both surveys, i.e. $71 \%$ of gross wages.

In light of the data obtained, the average costs of employee turnover can be estimated by evaluating the costs of hiring one new employee. The value of time spent was estimated based on the average gross wage in Slovenia in 2011. The average gross monthly wage was $€ 1,524.56$, and there were 2,080 annual working hours. The gross value of the work hour, which was used to estimate the costs of employee turnover, was $€ 8.80$.

\section{Tab. 4: Estimated costs of calls for applications and candidate selection}

\begin{tabular}{l|c|c} 
& $\begin{array}{c}\text { Time Spent } \\
\text { (in min.)/candidate }\end{array}$ & $\begin{array}{c}\text { Estimated cost in } € \\
\text { /candidate }\end{array}$ \\
\hline Costs of advertising a vacancy & & $0-300$ \\
\hline Review of applications & $5-10$ & $0.73-1.50$ \\
\hline Conducting an interview & $15-60$ & $2.20-8.80$ \\
\hline Medical examination & & 90 \\
\hline Total in $€$ & & $\mathbf{3 9 3 - 4 0 0}$ \\
\hline Costs of employee introduction & $15-30$ days & $152.45-304.91$ \\
\hline Costs of productivity loss & & $1,082.44$ \\
\hline Total cost of employee turnover in $€$ & & $\mathbf{1 , 3 2 7 . 8 9 - 2 , 0 8 7 . 3 5}$ \\
\hline
\end{tabular}

In addition to the estimated costs, we must also estimate the costs of introducing new candidates. As mentioned earlier, companies introduce candidates for 15-30 days. Since they are introduced by other employees, this means that the latter's workload increases. The workload increase permitted by law is $20 \%$; therefore, the cost of introduction was estimated at between $€ 152.45$ and $€ 304.91$, while productivity loss based on these data amounted to $€ 1,082.44$ per candidate. Given that in some companies new employees also receive training, it is necessary to factor this potential cost into the total amount.

The total cost of hiring a candidate thus ranges from $€ 1,327.89$ (the lowest estimated cost, which does not include the additional costs of advertising a vacancy, assumes minimum time spent and no additional training for the new employee) to $€ 2,087.35$. Various calculations are used for the employee turnover rate, and according to some calculations, the employee turnover rate in Slovenia is $30 \%$ (Cazes \& Nešporová, 2003), the annual employee turnover rate as a percentage of employees who changed their jobs in the last three months of 2008 for Slovenia was estimated at $4.4 \%$ (Federation of European Employers, 2011), while the average employee turnover rate as a percentage of all employees in the EU was estimated at $0.2 \%$ in 2008 (European 
Commission, 2011). Since in the relevant year the employee turnover rate in Slovenia was lower by only 0.2 percentage points, the cost of employee turnover for the entire economy can be estimated by assuming that the employee turnover rate in 2011 remained at about the same level. Thus the estimated total cost of employee turnover in Slovenia ranges from $€ 2.2$ million to $€ 3.4$ million per year. This is a relatively rough estimate of the cost of employee turnover, which entails a number of assumptions that must be taken into account when making an interpretation.

\section{Conclusions}

The present study shows that employees and employers do not evaluate the measures to reduce unwanted employee turnover in the same way. Most studies so far have focused solely on the perception of employees, while it is evident that employers, despite the large number of studies in this field, still do not perceive the measures preferred by employees to the same extent. Previous studies did not examine this; hence the importance of this paper in that aspect. Interestingly, there were no significant statistical differences in the estimates of measures between sectors or in relation to other characteristics of employees and employers. There are empirical studies, however, indicating that employee turnover rates vary from sector to sector. As has already been mentioned, most studies have focused only on specific sectors, and mostly in the U.S. at that, and fewer studies have been conducted in the EU (Aa et al., 2012; European Commission, 2011; Rhein, 2010) \& others (Yanadori \& Kato, 2007; Lee, Hsu, \& Lien, 2006). The contributions of studies conducted in other countries are thus important for increasing the exchange of knowledge and experience in this area as that is the only way to determine the impact of different cultures and traditions on the trend of employee turnover. Given that the present study included all sectors, the finding of different evaluation of certain measures is important for development and further research in this area. The prevention of unwanted employee turnover is important from several aspects, and the economic aspect, presented in this paper, focuses primarily on costs. The estimated costs in our study for Slovenia indicate that the costs of employee turnover per employee range from $87 \%$ to $136 \%$ of the average gross wage in Slovenia and that organisations lose an average of one monthly wage whenever replacing an employee, which results in lower productivity and work efficiency, especially if unwanted employee turnover is high. Measures to reduce employee turnover are therefore an important part of human resources management in organisations. It is evident that in evaluating measures employers give higher ratings primarily to financial measures (higher wages, working conditions), while employees prefer non-financial measures (praise, greater cohesion, trust in management), which require better management. In Slovenia, whose tradition stems from socialism rather than a democratic system, employers thus still emphasise employee non-differentiation, while employees want change. It is important for employees that the employer is able to differentiate between more and less successful employees and to create a positive atmosphere among employees and between employers and employees. That pay is not necessarily the most important element of employee turnover is also indicated by other studies that examined its impact on employee turnover (Lee, Hsu, \& Lien, 2006).

This study does have certain limitations. First, the sample included only those organisations that have active websites and only those employees who are affiliated with various employee organisations. We believe that organisations and employees would not provide essentially different answers as there were no statistically significant differences between sectors and other population characteristics in the present realised sample. Second, in estimating costs we did not perform weighting according to organisation size. Nevertheless, we wanted to take account of differences between companies, therefore we determined the amount of costs as an interval, taking into account the different responses depending on size. It should be noted, however, that the overall estimated costs of employee turnover would be lower if weighting were performed, but, unfortunately, we had no information on the employee turnover rate by company size, therefore such an estimate would not be relevant.

All these deficiencies notwithstanding, we believe that the results of the study will significantly contribute to the development of theory in the field of HRM, not only due to the 
different evaluations of measures for reducing employee turnover by the two groups included in the study, but also because these are the first such results and assessments in Slovenia, also contributing to international comparisons in this area, particularly on the part of the new EU member states or transition countries.

The study in its operational part was financed by the European Union, European Social Fund. Operation implemented in the framework of the Operational Programme for Human Resources Development for the Period 2007-2013, Priority axis 1: Promoting entrepreneurship and adaptability, Main type of activity 1.1.: Promotion of the development of new employment opportunities.

\section{References}

Aa, Z. van der, Bloemer, J., \& Henseler, J. (2012). Reducing employee turnover through customer contact center job quality. International Journal of Human Resource Management, 23(18), 3925-3941. doi:10.1080 /09585192.2012.669782.

Bennett, N., Blum, T.C., Long, R.G., \& Roman, P.M. (1993). A firm-level analysis of employee attrition. Group \& Organization Management, 18(4), 482-499. doi:10.1177/1059601193184006.

Bliss, W.G. (2007). Cost of employee turnover. Seneca, SC: Bliss \& Associates, Inc. Retrived May 21, 2011, from http://www. blissassociates.com $/ \mathrm{html} /$ articles/cost_of_ turnover15.html.

Bohlander, G., Snell, S.A., \& Sherman, A.W. (2001). Managing Human Resources. Cincinnati, $\mathrm{OH}$ : South-Western College Publishing.

Cascio, W.F. (2000). Costing human resources: The financial impact of behavior in organizations. Boston, MA: PWS-Kent Publishing Company.

Cazes, S., \& Nešporová, A. (2003). Labour Markets in Transition: Balancing Flexibility \& Security in Central and Eastern Europe. International Labour Office.

Cohen, A. (1999). Turnover among professionals: A longitudinal study of American lawyers. Human Resource Management, 38(1), 61-75. doi:10.1002/ (SICI)1099-050X(199921)38:1<61::AIDHRM6>3.0.CO;2-E.

Dalton, D.R., Cairns, D.A., Canavan, J.M.,
Downey, J.L., Fowler, A., Freiwald, G.M., Johnson, P., King, H.F., \& Lincoln, R.W. (1995). Human resource management and employee turnover and transfer: What we know is not always what we need to know. In G.R. Ferris, S.D. Rosen \& D.T. Barnum (Eds.), Handbook of human resource management. Cambridge, MA: Blackwell Publishers.

European Commission. (2011). Employment in Europe 2010. Retrived from: ec.europa.eu/ employment_social/eie/index_en.html.

Ettorre, B. (1997). Employee retention: Keeping the cream. HR Focus, 74,1-3.

Federation of European Employers FedEE. (2011). Pay trends across Europe: Labour costs and productivity. Retrived from: www.fedee.com/paytrends.html.

Kacmar, K.M., Andrews, M.C., Van Rooy, D.L., Steilberg, R.C., \& Cerrone, S. (2006). Sure Everyone Can Be Replaced... but at What Cost? Turnover as a Predictor of Unit-Level Performance. The Academy of Management Journal, 49(1), 133-144. doi:10.5465/ AMJ.2006.20785670.

Karan, M. (2011). Odsotnost $z$ dela - velik strošek za podjetja (Employee turnover substantial costs for organizations). Retrived from: http://www.saop.si/poslovne-informacije/ kariera-755/motivacija-komunikacija-in-zdravakariera/odsotnost-z-dela-velik-strosek-zapodjetja/.

Karsan, R. (2007). Calculating the cost of turnover. Employment Relations Today, 34(1), 33-36. doi: 10.1002/ert.20139.

Lee, C., Hsu, M., \& Lien, N. (2006). The impacts of benefit plans on employee turnover: A firm-level analysis approach on Taiwanese manufacturing industry. International Journal of Human Resource Management, 17(11), 19511975. doi:10.1080/09585190601000154.

McKinney, W.R., Bartlett, K.R., \& Mulvaney, M.A. (2007). Measuring the Costs of Employee Turnover in Illinois Public Park and Recreation Agencies: An Exploratory Study. Journal of Park and Recreation Administration, 25(1), 5074. Retrieved from http://js.sagamorepub.com/ jpra/article/view/1370.

Michaud, L. (2000). Turn the tables on employee turnover: Five keys to maximum employee retention. Home Healthc Nurse Manag, 4(5), 26-27.

Milkovich, G.T., Newman, J.M., \& Milkovich, C. (2005). Compensation. New York: McGrawHill//rwin. 


\section{Ekonomika a management}

Mitchell, O.S. (1983). Fringe Benefits and the Cost of Changing Jobs. Industrial and Labor Relations Review, 37(1), 70-78. doi:10.1177/001979398303700105.

Nobscot Corporation. (2006). Latest BLS Employee Turnover Rates For Year Ending. Retrieved from: www.nobscot.com/survey/ index.cfm.

Parise, S., Cross, R., \& Davenport, T. (2006). Strategies for preventing a knowledgeloss crisis. MIT Sloan Management Review, 47, 31-38.

Rhein, T. (2010). Ist Europa auf dem Weg zum "Turbo-Arbeitsmarkt? (IAB-Kurzbericht 19/2010). Institut fuer Arbeitsmarkt- und Berufsforschung. Retrived from doku.iab.de/ kurzber/2010/kb1910.pdf.

Rosch, P.J. (2001). The quandary of job stress compensation. Health and Stress, 3(1), 1-4.

Shaw, J.D., Gupta, N., \& Delery, J.E. (2005). Alternative Conceptualizations of the Relationship between Voluntary Turnover and Organizational Performance. The Academy of Management Journal, 48(1), 50-68. doi:10.5465/AMJ.2005.15993112.

Tracey, B., \& Hinkin, T. (2008). Contextual factors and cost profiles associated with employee turnover. Cornell Hospitality Quarterly, 49(1), 12-27. doi:10.1177/0010880407310191.

Chang, W., Wang, Y., \& Huang, T. (2013). Work Design-Related Antecedents of Turnover Intention: A Multilevel Approach. Human Resource Management, 52(1), 1-26. doi:10.1002/hrm.21515.

Waters, V. (2003). Recruitment \& retention report. Overcome hidden expenses, migrating staff. Nursing Management, 34(5), 20-24.

Yanadori, Y., \& Kato, T. (2007). Average employee tenure, voluntary turnover ratio, and labour productivity: Evidence from Japanese firms. International Journal of Human Resource Management, 18(10), 1841-1857. doi:10.1080/09585190701570981.

Yaniv, G. (1995). Burnout, absenteeism, and the overtime decision. Journal of Economic Psychology, 16(1), 297-309. doi:10.1016/01674870(95)00011-C.

Assist. Jernej Buzeti, Ph.D. University of Ljubljana, Faculty of Administration jernej.buzeti@fu.uni-lj.si

Full Prof. Maja Klun, Ph.D. University of Ljubljana, Faculty of Administration maja.klun@fu.uni-lj.si

Assoc. Prof. Janez Stare, Ph.D. University of Ljubljana, Faculty of Administration janez.stare@fu.uni-lj.si 


\title{
Abstract
}

\section{EVALUATION OF MEASURES TO REDUCE EMPLOYEE TURNOVER IN SLOVENIAN ORGANISATIONS}

\author{
Jernej Buzeti, Maja Klun, Janez Stare
}

This paper provides an estimate of the costs of reducing employee turnover and an estimate of the costs of employee turnover in Slovenian companies. The study included all economic activities, and in this respect it is one of the few studies that focus on the complete economy of an individual country. The study estimated two groups of costs; namely, the costs of employee-preferred measures for reducing employee turnover rates in organisations and the average costs of replacing an employee in an organisation. When evaluating the costs of employee-preferred measures we mainly wanted to evaluate the costs of subsidising informal meetings, bonuses for the continuity of employment and bonuses for workplace attendance. Most other measures preferred by employees are of a non-financial nature, except for promotion, which we did not evaluate specifically as it is primarily part of the company's employment and job diversity policy. In estimating the costs of employee turnover we focused only on the costs of hiring a new employee: the cost of replacing an employee and the cost of introducing the new employee. Using several assumptions the estimated total cost of employee turnover in Slovenia ranges from $€ 2.2$ million to $€ 3.4$ million per year in year 2011.In addition to the estimations of both groups of costs, this paper also provides a comparison of evaluations of selected measures for reducing employee turnover as perceived by employees and employers. We arrived at important conclusions, as it turned out that employers give higher ratings to financial measures, while employees give higher ratings to non-financial measures.

Key Words: Employee turnover, costs of turnover, financial measures, non-financial measures, human resource management, Slovenia.

JEL Classification: J24, J30.

DOI: 10.15240/tul/001/2016-1-009 